\title{
特集 外傷
}

救急処 置

杉本 㑆 ${ }^{*}$ 山田良平島崎修次

\section{はじめに}

外傷患者の初期治療にあたって，まず注意す べきことは全身管理の必要性を早くみきわめる ことである. 局所治療のみで足りる症例か， あ るいは全身管理が必要か, さらに全身管理とし て，まずなにから行ならべきかの判断が重要で ある。この判断は重症例ほど必要であるが必ず しも容易でなく成書にも総花的で常識的な記載 がなされているに過ぎない。

全身管理を困難にするもら一つの理由は局所 をどの程度重視すべきかの判断が一般外科的な 常識とやや異なる点にある。たと学ば腹腔内出 血でショック状態にある時に開腹手術をいかに 行ならかがその一例である. 外科の一般常識に よれば，まず全身管理によってショック状態を 脱した後に手術を行ならのが普通であるら。し かし，もし内出血が急速であればあたかもザル に水を入れるような状態になり動物実験に拈け るコントロールショックに類似した状態になり かねない。このような基本的方針の誤りから患 者を死に至らせる症例は決して珍しくない．

外傷の中でも最近頻発する多発損傷において はこの判断が特に重要である. 全身管理と救急 手術の比重を正しく判断し順を追ってすすめて 行くことが必要である.

本論文に拈いては以上のごとき観点から重度 外傷初期の病態のらち直接に生命を左右する循 環と呼吸の問題を中心にのべ，その救急処置に 触れて行きたい。

\footnotetext{
$*$ 大阪大学医学部特殊救急部
}

\section{I. 循 環 系}

救急外来に搬送された外傷患者のうち血圧が 低下しショック状態に陥入った症例に遭遇する ことは珍しくない，成書によればこの時期にお。 いては一次ショックと二次ショックがあり前者 の場合は神経反射によるもので，後者は失血に よるものと記載されている，神経反射による場 合は一過性で自然に軽快するが後者の場合は失 血の補いが必要で, 時には一次性ショックから 二次性ショックに変るから注意を要するとの記 載もみられる。この一次性ショックの分類がぞ のような背景を持って誕生したかは興味ある問 題であるが，実際の臨床面に括いては全く有害 無益な概念であると,われわれは考光る.神経反 射により血圧が下るとすれば副交感神経の異常 な興奮によるものであろらが，この場合は徐脈 が特徵でアトロピンにより回復しなければなら ないことになる。ところがこの型と断定できる ショックをわれわれはまだ一度も診たことがな く実際にどの程度存在するのか，はなはだ疑問 である。あるいは受傷後数分間以内にのみ存在 し，われわれのところに搬送された時には消兄 去っているのかも知れない，いずれにせよ外来 でショック患者を診た時には, この一次性ショ ックの概念は全く忘れ去った方がよく，なにか 機質的な変化によるものと考えるべきである.

外傷性ショックの場合には血圧低下の最大の 原因は循環血液量の減少にもとづくものであ る. 生理学的には平均血圧 $=$ 心拍出量 $\times$ 全末梢 抵抗によってあらわされるが，この全末梢抵抗 が特異的に下るタイプのショックは外傷の場合 


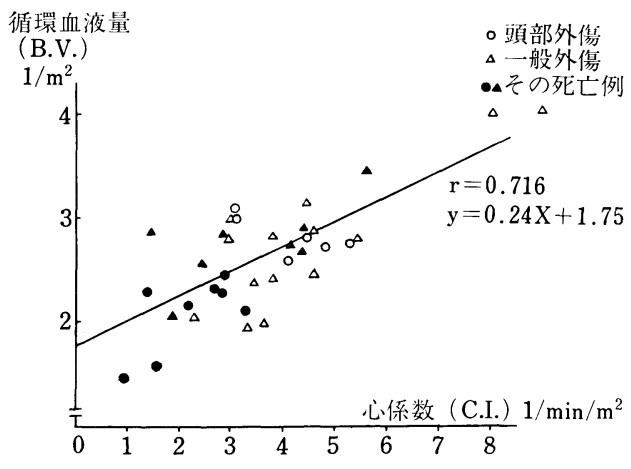

図 1 外傷患者における心指数と循環血液量の 関係。両者の間にはきわめて高い相関が ある。

にはまずみあたらない（最近，はじめてこの型 のショックに遭遇したが，皮膚は暖かく顔色も よく重篤感の全くない特異な型で一見して鑑別 はあきらかである).

通常の外傷性ショックの場合に全身の皮膚は 蒼白で冷たく切開しても血管は収縮して出血す らしないのが普通であり心拍出量の低下に対し て全末梢抵抗は最大限に上昇して血圧を維持し よらとしていることがうかがえる。この心拍出 量低下の最大の原因は循環血液量の減少に基つ” くもので，われわれの実測によっても両者に はきわめて高い相関が見出されている(図 1 ). したがって外傷性ショック患者の治療は，まず 輸血・輸液から開始しなければならない。われ われはテフロン針でまず 2 カ所の静脈を確保 し，一方からは代用血漿（主としてデキストラ ン）他方からはラクテートリンゲルの急速点滴 を開始する．同時に中心静脈へカニューレを插 入しここにもラクテートリンゲルを接続し圧 の測定と採血ならびに輸液路として使用する。 この間に動脈血を採取し血液ガスの分析と $\mathrm{pH}$ の測定を行なう。血液型を検查し輸血の用意を 行なってデキストランが $1,000 \mathrm{cc}$ 以上必要にな った時点で輸血への切り換えを考慮する必要が ある。この輸血・輸液は原則として血圧が上昇 するまで続けてよいが CVP を併せて観察すれ ばさらに安全である。

これらの処置により，もし血圧が回復せず CVP も低い值にとどまる場合には，腹腔や骨
盤腔に相当な内出血が続いていると考えるべき である，輸血・輸液を急ぐとともに手術的な止 血を考慮しなければならない，腹腔内出血であ れば原則として開腹して止血を行なわない限り 状態は良くならないから可及的速やかに手術を 行なわねばならない，止血に成功すれば状態は 急速に回復する。

この時期に血圧が上昇しないために難治性シ ョックとして，われわれのところに転送されて くる患者の大部分は失血の補いが不十分である かまたは内出血に対する評価が不適切な症例 である，成人の場合に血圧下降が起こるため には少なくとも $1,000 \mathrm{cc}$ 以上の出血が必要であ る1) 3). したがって受傷後30分以内に血圧が下 降する場合には続く 30 分間に少なくとも 2,000 ccの輸血を行なわない限り失血の補いができな いのは当然であろう。このような例に限ってス テロイドや，止血剤あるいは昇圧剂の大量投与 のみが十分に行なわれているのが普通である. 人間の出血性ショックは最後まで輸血, 輸液に よく反応し犬にみられるごとき非可逆性ショッ クの型を取るものはきわめて稀である。したが ってこれらの薬剤投与を考慮するより失血の補 いに全力を傾注する方がはるかに重要である.

失血以外に血圧下降の原因となり得るのは心 タンポナーデや緊張性気胸などにより胸腔内圧 の異常な上昇をきたした場合である。患者に意 識のある場合には胸内苦悶や呼吸困難があり異 常な胸廓の動きを伴うために鑑別は必ずしも困 難ではない，しかし来院後短時間で心停止に至 る重症例ではその原因を診断することは不可能 な場合が多い。

頭部外傷単独の場合は大出血がない限り血圧 の下降は起こらない，血圧の下降を起こす唯一 の原因は脳死またはその直前の状態になった時 のみで一般には他に複合損傷があると考学るべ きである4).

外傷患者が心停止をきたした場合には体外式 心マッサージをあまり繰り返しても無駄で開胸 式の心マッサージに早く切りかえるべきであ る。開胸すれば胸腔内压の異常はただちに診断 治療されらる，失血による心停止の場合には心 
臓は空虚な肉塊と化し中に血液が注とんど存在 しないから体外式のマッサージでは効果は望め ない。したがって診断と治療をかねて開胸式の 心マッサージを行ならべきである。

\section{II. 呼吸管理}

受傷直後に呼吸障害が発生するのは胸部外傷 と頭部外傷である。一般外傷については救急処 置としての問題は比較的少ないが，後に重篤な 呼吸障害へと発展する例のあることを知らねば ならない，以上につき各論的にのべたい．

\section{1. 胸部外傷}

胸廓の損傷, 胸腔内圧の異常, 肺そのものの 損傷などのいずれの場合においても重篤な呼吸 障害が発生する。このうち寸刻を争って処置す べきものは胸腔内压の異常で特に緊張性気胸が 重要である，注意して観察すればその重篤な呼 吸困難や一側胸廓の膨隆, 呼吸運動の左右非対 象によって気がつくはずである.

多くは広範な皮下気腫を合併するし，聴打診 で明白な所見を得るから診断は必ずしも困難で はない，ただらに試験穿刺を行ない胸腔ドレナ 一ジを留置して持続吸引を開始すべきである。 そのうえで IPPBを必要に応じて持続的または 間歇的に行な壳ば良い，血胸に対しても基本的 には同一の処置をとれば救急処置としては十分 である．以上の処置によってもコントロールで きないよらな出血や空気の漏れがある時には救 急手術を考慮する必要がある5).

重篤な胸廓の損傷がある時には疼痛と病的な 呼吸運動のために著しい呼吸障害が発生する。

これに対して救急的には鎮痛剂の投与と胸壁の 固定で対処してょいが，これはあくまで一時的 な処置であることを忘れてはならない，重篤な 胸部の損傷がある時には患側肺に換気障害と分 泌の元進 ${ }^{6)}$ が起こるらえ有効な咳嗽が非常に困 難となる、したがって無気肺から traumatic wet lung の発生する危険性が非常に高い，この危 険性は肺挫傷を伴ら時にはさらに強い。 flail chest の発生している場合には胸壁の病的運動 が著しいことのほか，大部分に肺挫傷を合併し ているために，単なる胸壁の固定のみでは死亡

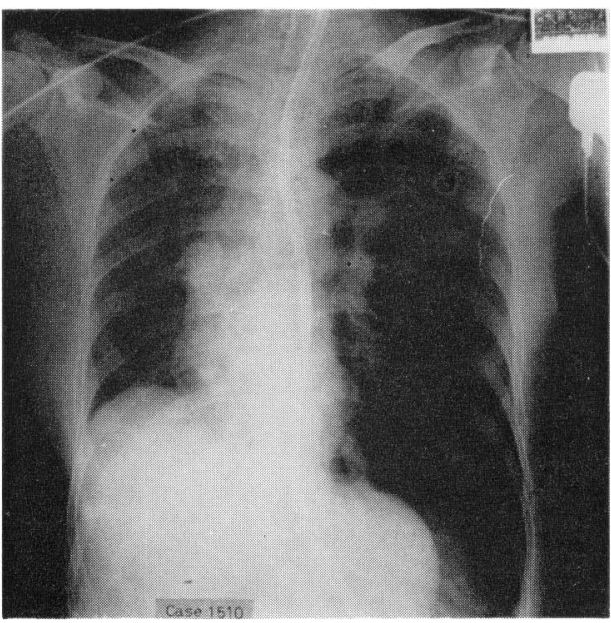

図 2 IPPB を開始した後で発症した緊張性気胸 の一例.

率が非常に高いことは，よく知られている通り である。したがってできるだけ早期に IPPBを 開始することが必要である，IPPB を持続的に 行なわなければならない時（大部分の flail chest および重症の肺挫傷例）には気管内插管が必要 となる，気管切開は挿管を48時間以上続けなけ ればならない時に考慮すればよく，原則として 救急的に行なわれることはない，これは胸部外 傷にかかわらず救急処置一般にいい得ることで ある。

胸部外傷患者に IPPB を行ならにあたり，も っとも注意すべきことは緊張性気胸の発生であ る。IPPBによって単なる気胸も緊張性気胸と なる。それのみならず潜在的に存在していた肺 損傷の部位から空気の漏れが起こり緊張性気胸 へと発展する場合がある5)、気管内插管を行な い十分な鎮静剂が投与されている症例ではこの 合併症は特に危険である。患者は苦痛を訴皃な いし呼吸は機械的に補助されているために一見 正常にみえる。したがって診断が遅れて死に至 る症例すら報告されている7)。図 2 は IPPB 開 始後 5 時間目に発生した緊張性気胸の一例であ やうく死に至る症例であった。 IPPB を行なう 必要のある時にはこの事実を十分に念頭に置く べきであろう，少しでも血気胸を合併している 時には持続胸腔ドレナージを留置しておくのが 安全である。 


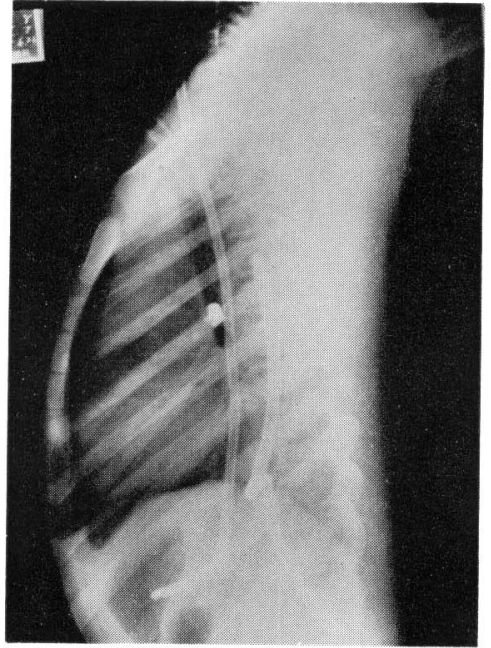

図 3 頭部と胸部に合件損損のある一例に見ら れた蕋の誤领。口腔に大きな損傷があり 救急的に気管切開と胸腔ドレナージが行 なわれている。毛後のレントダン撮影で この気管異物がはじめて発見されている。

\section{2. 頭部外傷による呼吸障害}

このらち受傷直後に重要なのは 1) 䛊飲と 気道内異物 2) 中枢性の呼吸抑制 3 ) $\mathrm{PaO}_{2}$ の特異な低下の三つに集約できる。これらは後 に頭部外傷に特有な呼吸障害へと発展するが救 急処置としては，さしあたりこの三つに考慮を 払えば良いであろう。

\section{1 ) 誤飲と気道内異物}

頭部外傷のらち意識消失を伴うものには気管 内に䛊飲をしている症例が多い，特に鼻腔や口 腔，頭蓋底に損傷を受け出血している患者の場 合はほとんどすべてに血液の誤领がみられる。 時には折れた歯牙が気管内に落ら込んでいる場 合がある．図 3 はそのような一例のレントゲン 像を示した。この症例の場合は主として左気管 支を并状に閉塞し, やがて左側肺の著しい肺気 腫を生ずるとともに $\mathrm{PaCO}_{2}$ の上昇をるたらし た. 血液とともに吐物の䛊领も非常に多い, 手之 ーインガムやあめ玉，さらにはフロントガラス の破片が気管内から発見されることもある。

したがって昏睡状態にある頭部外傷に対して は, すべてに気管内插管を行ない気道内の吸引 を試みるべきだとわれわれは考える。ここでも し吐物が吸引されれば生理的食塩水で繰り返し

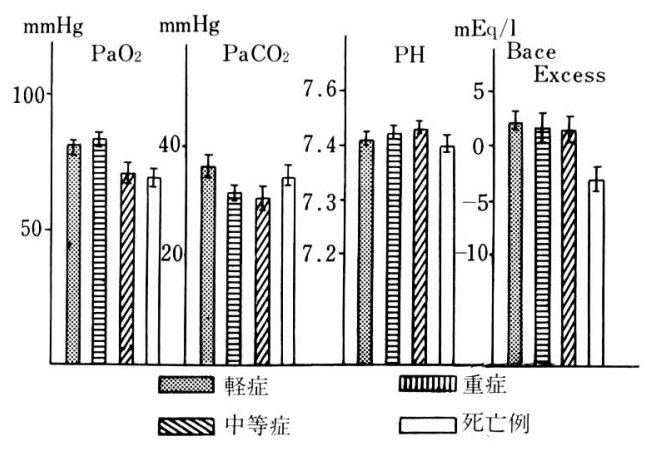

図 4 頭部外傷患者来院時の血液ガス. $\mathrm{PaO}_{2}$ は 重症例の方が低いが $\mathrm{PaCO}_{2}$ は逆に下る傾 向にあり hypoxia と hyperventilation $の$ 組み合わせとなっている。

トイレッテングを行なわなければならない.

気管内插管に際しては今のべた種々の異物が 咽喉部に落らこんでいることが多いので，この 点を十分に確認しなければならない。

不注意な気管内插管によって，これらの異物 を気管内に押し込む危険性がきわめて高い．

\section{2 ）中枢性の呼吸抑制}

成人の場合は重篤な症例活ど呼吸は促進し hyperventilationが起こるのが普通で中枢性の呼 吸抑制をきたすことはむしろ稀である。呼吸運 動が異常に緩徐になったりあるいは停止するの は匡とんど末期症状で herniation から脳死へ の過程にある場合のみといってよい，図44来 院時に室内空気, 自発呼吸の条件で動脈血を採 血し測定した結果である。換気の状態は $\mathrm{PaCO}_{2}$ によって一応の判断が可能であるがこの図でみ るごとく後に死亡したり遷延性昏睡に陷る重症 例の方が $\mathrm{PaCO}_{2}$ は低く hyperventilation をし ていることがわかる。これに反し小児の場合は 軽症な例にかえって強い呼吸抑制の起こること に注意を要する，われわれが 6 歳以下の頭部外 傷患児を検查した結果によると受傷後 12 洔間以 内に意識回復のみられる軽症例ではきわわて高 頻度に $\mathrm{PaCO}_{2}$ の上昇と $\mathrm{PaO}_{2}$ の低下が認められ た.この時期には臨床的にも浅薄で不規則な呼 吸が認められ顔面は血色を失いチアノーゼに近 い状態になっているものが多い、したがってこ の換気不全はかなり高度なものであるが大部分 
は受傷後 1 時間半以内に回復する。 これより重 症なものでは, かえって最初から hyper-ventilation の起こることが多い. 以上のように比較 的軽症な小児に中枢性の呼吸抑制が起こること は非常に重要なことといえよう（図５）。このよ らな呼吸抑制状態にさきにのべた誤飲や気管内 異物が加わる時は容易に致死的となる．このよ らな患児に対しては，ほんの $1 \sim 2$ 時間気道の 確保と機械的呼吸を補助するだけで容易に危機 を脱することができるから初療を行なら医師の 責任はきわめて重大というべきである.

\section{3 ) $\mathbf{P a O}_{2}$ の特異な低下}

中权性にせよ，誤飲によるものにせよ，換気 の障害によって $\mathrm{PaO}_{2}$ が低下することは疑らべ くもない，乙かし大部分の症例では逆に過呼吸 の状態で $\mathrm{PaCO}_{2}$ は低下しているにもかかわら ず $\mathrm{PaO}_{2}$ の相当な低下がある点に重要な問題が ある.この $\mathrm{PaO}_{2}$ の低下は重症なものほど強 く，しかも長期にわたり続く傾向にある。しか も高濃度酸素投与に対する反応が乏しい点に特 徵がある。

レントゲン的には初期には必ずしも特徵的な 変化はなく時に種々な程度の肺浮腫と無気肺が 認められるに過ぎない，頭部外傷に伴ら急性肺 水腫の発生は一般に信じられている程多いもの ではない，この時には非常に強い $\mathrm{PaO}_{2}$ の低下 が起こるが受傷直後に発生するものは一過性で 強力な呼吸管理さえ行なえば比較的短時間で回 復するのが普通である ${ }^{8)}$.

頭部外傷に伴うこの $\mathrm{PaO}_{2}$ の低下については その本態が全く不明であるが，われわれは肺胞 に neurogenic な反応が起こったためと考えてい る。技そらく細静脈のあたりに異常な攣縮が起 こり毛細管圧が上昇して肺胞壁の浮腫と肺胞内 への㴉出が起こる結果, ガス交換の障害が起こ るものと推定したい，急性肺水腫はこのよらな 状態が極限にまで達した時に発症するものと考 えられ, 実験的には preoptic region を刺激す ることにより発生させることができる ${ }^{9)}$.

頭部外傷患者の呼吸障害は以上のごとき変化 が基礎になって後に酸素中毒や感染が病像に修 飾を加えた時に, 致死的な病変へと進展するも

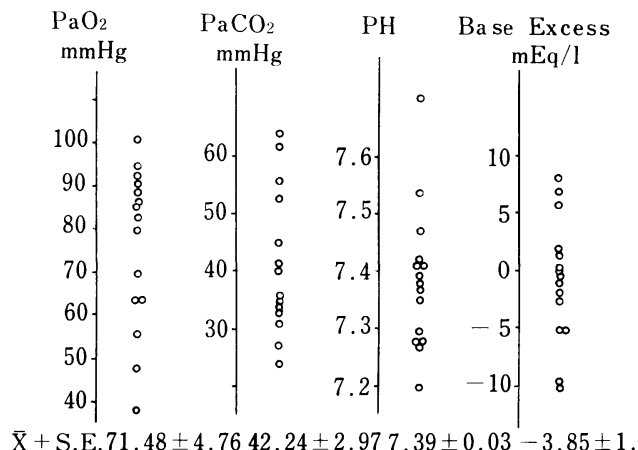

図 56 歳以下の軽症頭部外傷小児（12 時間以 内に意識を回復）に拈ける来院時の血液 ガスと酸塩基平衝， $\mathrm{PaCO}_{2}$ の著しい上昇 例がみられる。この群においては $\mathrm{PaCO}_{2}$ の下降と $\mathrm{PaO}_{2}$ の低下がょく一致していた。

のと考えられる.

この $\mathrm{PaO}_{2}$ の低下に対しては特殊な治療法は ない，血液ガスの測定を行なって必要な酸素療 法を行ならことが中心で後は呼吸管理の原則を 忠実に守って治療を続けるよりほかにない。 CPPB を推奨する論文もみられるが，われわれ の経験によれば特効的な効果は期待できないよ らである。

\section{3. その他の外傷}

頭胸部に外傷のない時は一般に救急的な呼吸 管理はそれほど必要ではない. 出血性ショック の患者は促迫した荒い呼吸をしており，いかに も呼吸困難があるように感じられるが，これは 主としてメタボリックアチドージスに対する代 償的な hyperventilation に過ぎない10).

したがって輸血・輸液をはじめとする循環系 の管理が中心で気管内插管や酸素療法に気を奪 われてはならない，ただし出血死直前の状態に なると突然あくびをした後でチェーンストーク 呼吸になるから，ただちに補助呼吸を開始する とともに輸血, 輸液を最高に急がねばならな い. 放置すれば数分以内に確実に心停止に至り その蘇生は非常に困難となる。

一般救急患者の呼吸機能を論ずるにあたって もっとも重要な問題はショック肺の発生であ る. ショックが遷延した場合にはその回復後に 必ず $\mathrm{PaO}_{2}$ の低下が起こることは留意しておく 


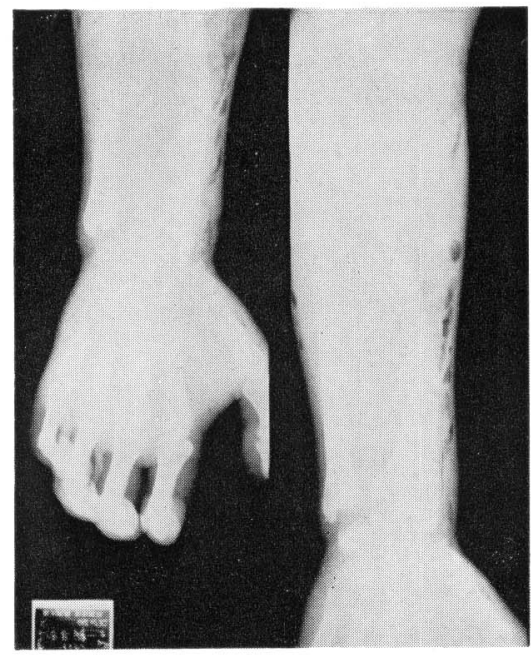

図 6 前腕の開放骨折から発症したガス壊疽の 一例.

べきである ${ }^{11}$ ，大部分の症例は face mask によ る酸素投与で必要な $\mathrm{PaO}_{2}$ の維持が可能である が中にはきわめて重篤で IPPB による高濃度酸 素投与が必要な症例もある。このような事態は 受傷後, 早くとも24時間以上経過した後でしか あらわれないから救急処置の範疇を外れるがそ の存在に対する留意は必要である。

\section{III. 救急手術の準備}

以上のごとく循環と呼吸の管理は重度外傷の 初療にあたって非常に重要であるが同時にその 原因となっている受傷部に対する根治的な処置 をすすめて行かなければならないまた，重複 外傷の場合はどの部位の処置から開始すべきか も問題である.

局所的な問題に関してはまず大量出血に対す る止血をもっともいそがねね゙ならない，四肢の 場合は駆血帯によって一応のコントロールが可 能であるから，その救急処置は容易である，胸 部外傷については既にのべたごとく胸腔ドレナ ージと機械的な補助呼吸で救急的な処置は完了 できるからさしあたっての問題は少ない。

腹部外傷による内出血は他部位の外出血と同 様に可及的速やかに止血をはからなければなら ない，目にみ党る出血があれば，われわれはす べてに先立ってその止血をはからうとするが，
内出血に対しては，ともすれば消極的になりが ちである．腹腔内の大量出血岋自然に止血され ることがないからこれを放置して找计ば全身状 態の根本的な回復はあり得ない.したがって全 身管理と救急的な開腹は平行して行ならべき で，全身状態の回復を保ってから手術を行なう といら態度はまちがいである。

頭部外傷に抢ける頭蓋内血腫の除去手術は救 急を要するが手術の効果からみて他の部位の処 置よりるこれを優先させることはできない，乙 たがって脸血管撮影のごとき手術の適応を決定 するための諸検査も，上にのべたすべての処置 が終わってからのことになる。

污染創の処置についてはどのよらな救急事態 になろらとも brushing と debridementを莣っ てそのまま縫合することは許されない。もし胸 腹部の処置などのため污染創の処置が遅れる場 合には一応止血と抗生物質の散布を行なって新 鮮なガーゼで覆って抔く，しかしこの場合も brushing, debridement を6 時間以内に行なわ ないと有効な結果を得ることはできない12)。污 染創に対し簡単な消毒の後に一時的な縫合が行 なわれ，数日後にガス壊疽や破傷風を発症して われわれのところに転送されてくる患者が現在 も非常に多い．図 6 は前腕の開放骨折創からガ 又壊疽の発生した症例で抜系を行ない創を開放 すると木の破片が発見されている。

全身麻酔が行なわれている間に全身の創に対 し処置を行なら方が簡単で徹底的な処置を行な いやすい，開胸や開腹術を行なった後では術者 も疲労しているが，ここで手をゆるめては千仍 の効を一気に欠くことになる。創の機械的な清 掃と壊死組織の除去は外傷が大さい時注ど重要 なことを忘れてはならない。

\section{おわりに}

重篤な外傷患者に遭遇した場合にはまずなに よりもその全身管理に十分な意を払ら必要があ る。その中でも呼吸と循環に対する処置はもっ とも重要であるが，すべてを総花的に行なえば すむといらものではない，局所的な治療もまた 全身におよぼす影響の大なるものから処置して 
行く必要があり, 場合によっては常識的な全身 管理より優先させね柿ならないこともある。こ れらの判断はすべて外傷の病態を中心に考慮し て行ならべきで一般外科の常識では類推できな い問題も多い.

多発損傷に打㤝手術や処置の順序もまた非 常に重要である．現在は外科の各領域が細分化 されているため各科の専門医によって一定の方 針がないままに処置されていきがちである。こ の場合も全身的な立場から統一的な管理を行な ら必要がある。

本論文はこのような立場から各部位の外傷の 病態を解説し，そのうえに立ってまず行なうべ き重要な救急処置をのべた。ここに記載した処 置のほかにトキソイドや抗生物質の全身投与を はじめ種々の薬剤の使用法も重要である.また, 血液凝固と線溶に関してもその病態に対する理 解が不可欠である. しかしこれらの問題につい ては紙面の都合上すべて割愛せざるを得なかっ
た。われわれの著書13)を参照して頂ければ幸い である。

\section{文献}

1) Burri, C.: Lang. Arck. klin. Chir., 320; 1, 19 68.

2) Moore, F.D.: Metabolic care of the surgical patient. W.B.Saunders Co. 1959.

3）杉本㑆汪か：外科治療, 22; 345, 1970.

4）山田良平注か：脳と神経，23；889，1971。

5）杉本㑆良：外科治療, 27；518, 1972.

6) de Takats, G. et al.: J. A. M. A., 120; 686, 1942.

7) Blair, E. et al.: J. Trama., 11; 129, 1971.

8）野中家久伍か：外科治療， 28；111，1973,

9) Urabe, M. et al.: Japan Heart J., 2; 147, 1961.

10）杉本㑆汪か：日外会誌， 73；242, 1972 .

11）杉本㑆汪か：外科治療，27；27，1972.

12) Elek, S.D. and Conen, P.E.: Brit. J.Exp. Path., 38; 573, 1957.

13）杉本㑆編著：外傷外科学, 医菌薬出版 (印刷中).

\section{* 東京医学社刊行雑誌*}
(月 刊)
周㢆期医学
(月 刊)
(月 刊)
(月 刊)
(月 刊)
(季 刊)

提休と胎児との関係情報を明確にキャッチする 定価 700 円半年 4,300 円 (共) 1 年 8,400 円 小睍綜合医療鹤诘

定価 700 円半年 4,300 円（下共） 1 年 8,400円 成人病綜合医療権誌

定価 $600 \mathrm{円}$ 半年 4,000円(共) 1 年 7,200円 心臟・脈管・血液疾患の専門雑誌 定価 700円 半年 4,300 円(共) 1 年 8,400円 臨休家のための免疫学雑誌

定価 $700 \mathrm{円}$ 半年 $4,300 \mathrm{円}$ ( 共) 1 年 $8,400 \mathrm{H}$ 鞭打ち損傷，頭部外傷の診断と治療に

定価 1,000円（干200）

1 年 4,400 円 